\title{
Serum Potassium Measurement
}

National Cancer Institute

\section{Source}

National Cancer Institute. Serum Potassium Measurement. NCI Thesaurus. Code C61030.

A quantitative measurement of the amount of potassium present in a sample of serum. 